\title{
THE EFFECTS OF WORK ENVIRONMENTAL FACTORS ON JOB SATISFACTION: THE MEDIATING ROLE OF WORK MOTIVATION
}

\author{
Taghrid S. SUIFAN \\ Department of Business Management, The University of Jordan \\ Amman 11942 Jordan \\ E-mail: t.suifan@ju.edu.jo
}

Received 18 February 2019; accepted 05 July 2019

\begin{abstract}
This paper explores how work motivation mediates the association between work environmental factors and job satisfaction. The data were collected through a questionnaire survey administered to middle and top managers in Jordanian commercial banks. A total of 295 questionnaires were returned out of 500, with a response rate of 59\%. Validity and reliability analyses were performed, and direct and indirect effects were tested using structural equation modelling. Work motivation was found to positively and significantly mediate the effects of work environmental factors on job satisfaction. This finding is attributed to work itself and its contextual factors contributing to employees' positive feelings towards their jobs, depending on the effectiveness of their work motivation. This study fills a gap in the literature on how the psychological environment of the workplace affects work environmental factors.
\end{abstract}

Keywords: work environmental factors, work motivation, job satisfaction, job insecurity, quantitative demands.

JEL Classification: M19.

\section{Introduction}

In today's competitive business environment, employees are considered a company's most valuable asset and main source of financial gains and productivity (Singh et al. 2011). Thus, employees' job satisfaction is a vital concept in every organization. Job satisfaction is the extent to which employees' jobs fulfil their desires (Jayaweera 2015). Greater employees' satisfaction can lead to a healthy workplace and employees' well-being, whereas dissatisfaction brings extremely negative outcomes to the company (Halkos and Bousinakis 2017).

Job satisfaction represents individuals' attitudes toward the work-roles that they are presently occupying associated with work motivation (Sarrasin et al. 2017). There can be no job satisfaction without motivation (Dawal and Taha 2006). Motivation can be defined as a psychological drive that stimulates, directs, and influences individual behaviour (Snepenger et al. 2006). It is the driving force behind all of our actions (Rabideau 2005). Once employees realize that the company values them and considers them important, as manifested by offering rewards, bonuses, and promotions according to their skills and performance, they will be highly motivated, committed, and satisfied (Aksoy et al. 2018). A highly motivated workforce constitutes a competitive advantage for any organization (Tremblay 2009).

Recent studies suggest that work environment plays a major role in employees' job satisfaction (Agbozo et al. 2017, Abualrub et al. 2016). Employees need a flexible work environment that allows them to work freely and without problems (Raziq and Maulabakhsh 2015). A healthy work environment is characterised by physical and psychological conditions, procedures, structures, relationships, and policies that positively influence employees' satisfaction, motivation, and performance in the workplace (Singh et al. 2011). Physical work conditions are also commonly found to have an important impact on job satisfaction in the organization (Raziq and Maulabakhsh 2015, Bojadjiev et al.

Copyright (c) 2019 The Authors. Published by VGTU Press.

This is an Open Access article distributed under the terms of the Creative Commons Attribution License (http://creativecommons.org/licenses/by/4.0/), which permits unrestricted use, distribution, and reproduction in any medium, provided the original author and source are credited.. 
2015, Ayamolowo 2013). However, very few studies have specifically modelled and empirically tested the nature of the relationship between psychological work environmental factors and employees' job satisfaction (Arsalani et al. 2011, Bjorner and Pejtersen 2010, Kristensen et al. 2005). Examining this relationship offers important managerial insights into influencing employees' job satisfaction.

Given the paucity of literature in this area, this paper aims to explore the association between work environmental factors and job satisfaction, together with the role of work motivation in this relationship. Given the strong need to investigate these proposed relationships in a developing economy, the context selected for this study is that of the commercial banks in Jordan. The following two research questions are addressed:

$R Q 1$ : What is the impact of four work environmental factors (quantitative demands, job insecurity, social support from supervisors, and role clarity) on job satisfaction?

$R Q 2$ : How does work motivation mediate the association between work environmental factors and job satisfaction?

Section 1 discusses the literature on job satisfaction, work environmental factors, and work motivation. Then, it formulates hypotheses for examining the proposed relationships. Section 2 details the study's empirical method, through which data were collected from 295 middle and top managers in Jordan's banking sector. After presenting and discussing the results in sections 3 and 4 , the last section offers some conclusions.

\section{Literature review}

\subsection{Work environmental factors}

The work environment in which employees operate and perform their daily tasks is one of the most critical factors continually affecting their productivity and satisfaction (Wilson 2015). It comprises two major dimensions: the work itself and the context. Work refers to job characteristics, the way tasks are carried out, and all related activities. Context comprises the physical and social working conditions (Raziq and Maulabakhsh 2015). It can also be perceived to combine three dimensions: the technical, the organizational, and the human environment. The technical environment includes equipment and tools; the organizational environment comprises the organizing philosophies, systems, and practices; and the human environment refers to groups, teams, and peers with whom employees interact. All three should be designed in a manner that encourages employees to effectively perform and interact in the workplace (Opperman 2002).

Spector (1997) argues that a positive work environment assures employee safety, motivates and acknowledges good performance, provides job security, induces stable relations among peers, and allows employees to participate in decision-making processes. Lane et al. (2010) highlight that numerous factors within the organizational environment, such as salary, working hours, employees' autonomy, organizational structure, and communication between employees and supervisors can all impact job satisfaction. Relatedly, Wen Lim et al. (2018) emphasize the importance of a workplace's safety climate, which significantly affects safety motivation and, in turn, safety performance.

Based on the many identified dimensions of the work environment, two fundamental categories are commonly recognised: physical factors and psychological factors (Arsalani et al. 2011). This empirical analysis focuses on psychological factors, the most commonly analysed of which are quantitative demands, job insecurity, social support from supervisors, and role clarity (Bjorner and Pejtersen 2010, Kristensen et al. 2005).

The concept of quantitative demands in the workplace is defined as the amount of work required to an employee. The possible mismatch between the time available and the amount of time needed to complete the assigned tasks is a potential source of stress (Kristensen et al. 2004). Kristensen et al. (2005) argued that quantitative demands should be considered in association to some psychosocial factors such as stress, employees' well-being, and some personality factors in order to enhance and facilitate research on this topic and practical workplace interventions.

Job insecurity refers to the subjective perception that individual's job is at risk or unstable. Since it is often accompanied by stress, fear, and anxiety, it is a key psychosocial risk that can cause significant problems for organizational performance and employees' mental and physical health (Probst et al. 2017). Subjective job insecurity often derives from a previously signalled threat that aggravates an employee's perceived fear or worry about the future of their job. There is variation in the extent of employees' dependence on their current jobs because this is governed by economic factors (financial security), transferable skills, and the availability of employment protection legislation (Green 2011). Workers with permanent contracts feel more secure than those who have temporary ones (De Cuyper and De Witte 2007).

The concept of social support has become very popular and pervasive in the analysis of various organizational outcomes, such as satisfaction, commitment, turnover, and burnout (Lucas et al. 2009). Social support provides employees with feelings of attachment to groups and individuals (House 1981). Social support can be emotional (listening to peers' problems, providing sympathy and consultation), informational (giving information and advice), and instrumental (help getting the task done) (Sias 2009). Within an organization, social support comes from two sources: co-workers and supervisors (Appu and Kumar 
2015). Supervisor support is the extent to which supervisors provide encouragement and support to employees within their work teams (Griffin et al. 2001). It is also the degree to which a manager or supervisor reinforces and encourages training in the workplace (Suleiman et al. 2017).

Role clarity concerns the extent to which individuals comprehend the responsibilities, duties, tasks, and expectations of their work roles (Lee and Lee 2017). It acts as a vital enabler in formulating and maintaining collaborative work practices (Curnin et al. 2015) and focuses on limiting ambiguity over exactly what an employee is expected to do (Jackson and Schuler 1985). Some studies suggest that working in teams and reporting to several managers can improve clarity in tackling more complex and abstract tasks, but other studies have shown that multiple roles and communication channels may also create ambiguity and conflicts (Henderson et al. 2016).

\subsection{Work motivation}

Work motivation is an effective tool to enhance employees' performance with respect to organizational, personal, and cooperative goals (Alhassan et al. 2013). Ryan and Deci (2000) identify competence, autonomy, and relatedness as the three fundamental psychological needs that individuals try to satisfy. In the work environment, two types of motivation are relevant to these needs: intrinsic motivation and extrinsic motivation. Intrinsic motivation derives from work being inherently interesting or enjoyable, while extrinsic motivation is reward-driven behaviour. Rewards and other incentives are used as motivations for specific activities. As such, motivation can assist an individual to achieve job satisfaction and commitment to their role (Ahluwalia and Preet 2017).

In the literature, work motivation is analysed according to three major dimensions: intrinsic motivation, integrated regulation, and external regulation (Tremblay et al. 2009). "Intrinsic motivation" induces an individual to undertake an activity for its own sake as inherently interesting and satisfying; it represents a prototype of self-determined motivations, which lead to the most positive outcomes. "Integrated regulation" refers to the process of identifying with the value of an activity to the extent that it becomes part of the individual's sense of self. This is the most fully internalized form of extrinsic motivation, and so it is said to be autonomous (Tremblay et al. 2009). Finally, "external regulation" is a non-self-determined motivation, described as doing an activity only to obtain a reward, which leads to negative outcomes (Tremblay et al. 2009).

\subsection{Job satisfaction}

It is essential for today's organizations to ensure the psychological and social satisfaction of employees, since this should increase their desire to stay with the organization and enhance their work efficiency, leading to increased profitability for the organization (Aksoy et al. 2018). According to Spector (1997), job satisfaction entails employees' positive feelings towards their jobs. It concerns the extent to which employees' physical, mental, and social needs are met, and affects their happiness and levels of productivity and success in the workplace (Canan and Oksay 2015).

Ayamolowo (2013) highlights that job satisfaction is an emotional response resulting from the employee's evaluation of their work and work environment. Atefi et al. (2014) assert that job satisfaction is important in terms of the employee's performance, life satisfaction, and quality of life. Moreover, prior research has identified three primary dimensions of job satisfaction: rewards, job stress, and job characteristics (Alarcon et al. 2009, Clark et al. 2010, Fairbrother and Warn 2003, Hackman and Oldham 1976, Li et al. 2014, Wanous et al. 1997, Yuen et al. 2018).

Rewards are the most used tool to guide employees' behaviour and performance, aiming to attract and retain the best qualified and to keep them both motivated and satisfied (Bratton and Gold 2017). Rewards have recently been conceptualized as any valued outcome that employees receive from the employer in exchange for their hard effort and contribution (Henderson 2003). Thus, rewards can be financial (often termed "pay") and psychological. Prior research has distinguished intrinsic and extrinsic rewards (Ganzach and Fried 2012). Extrinsic rewards are external to the job itself and provide the means to support both personal and family goals, such as living in a nice neighbourhood and providing one's children with a good education. Intrinsic rewards are those that come from within the employee. An employee who is motivated intrinsically is working for his/her own satisfaction and may value challenging work perceived as being meaningful to the company.

Job (or role) stress refers to anything in the organization that may be detrimental to individual health and performance (Devi and Rani 2016). Job stressors predict job dissatisfaction and higher turnover intentions (Fairbrother and Warn 2003). The costs of the stress manifested at the individual and organizational level ultimately influence also society at large (Petreanu et al. 2013). Seckin-celik and Coban (2016) highlight several factors that might contribute to increase the level of stress. These factors can be intrinsic to the job (e.g. workload, time pressure, poor physical working conditions) or related to the organization (e.g. role conflict or ambiguity), career development (lack of job security and over/under promotion), relationships at work (e.g. poor relations with managers or colleagues), or organization climate (e.g. policies or level of participation in decision-making).

Regarding job characteristics, the content and nature of a job can positively influence job satisfaction (Bhattacharya 


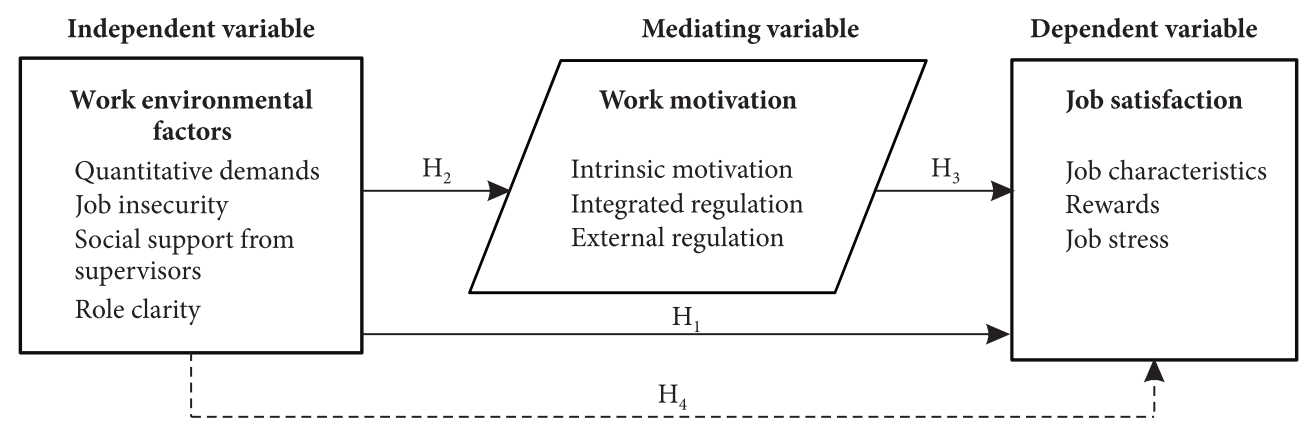

Figure 1. The conceptual framework of the study

and Sengupta 2007). According to Hackman and Oldham (1976), job characteristics comprise five core dimensions: skill variety, autonomy, task identity, feedback, and task significance. These dimensions represent the degree to which an employee's task entails variety in activities, constitutes a whole process, impacts on other tasks, and gives freedom in decision-making (Na-Nan and Pukkeeree 2013).

\subsection{Development of model and hypotheses}

The main premise of the paper is that an organization with the right work environmental factors to promote a healthy workplace is likely to motivate its workforce, which is likely to result in greater employees' satisfaction and well-being. The model is illustrated in Figure 1.

\subsubsection{Work environmental factors and job satisfaction}

One of the major challthe enges for an organization is to satisfy its employees, especially with dynamic changes in the modern work environment. Raziq and Maulabakhsh (2015) found a positive relationship between work environment and employee job satisfaction. Similarly, in a study of Ghana's banking sector, Agbozo et al. (2017) found that the physical, social, and psychological environment of the workplace has a significant effect on employees' job satisfaction. Singh et al. (2011) suggest that healthy work environment factors are those physical and psychological conditions, procedures, structures, relationships, and policies that positively influence employees' satisfaction, motivation, and performance in the workplace. Accordingly, the following hypothesis is proposed:

$\mathrm{H}_{1}$ : Work environmental factors such as quantitative demands, job insecurity, social support from supervisors, and role clarity are positively associated with job satisfaction.

\subsubsection{Work environmental factors and work motivation}

Work motivation and environment have been identified as key factors affecting performance. Muchtar (2017) examined the effect of the work environment on work motivation and the effect of both on business performance. A good work environment in which employees are conducting an optimal, healthy, safe, and comfortable job in conjunction with high motivation to work was found to influence organizational performance positively and, in turn, the achievement of organizational goals. Jayaweera (2015) explored the relationship between work environmental factors and job performance among hotel workers focusing on the role of work motivation. Working conditions and work motivation were both found to be important predictors of job performance, Accordingly, the following hypothesis is proposed:

$\mathrm{H}_{2}$ : Work environmental factors such as quantitative demands, job insecurity, social support from supervisors, and role clarity are positively associated with work motivation.

\subsubsection{Work motivation and job satisfaction}

One of the major challenges for a business company is to satisfy its employees in an ever-changing and evolving environment. Raziq and Maulabakhsh (2015) examined the relationship between work motivation and job satisfaction in educational, banking, and telecommunications organizations in Pakistan. Their study revealed a positive relationship between work environment and job satisfaction. Motivation derives from the nature of work, the sense of achievement obtained from work, and the related rewards. Managers should pay attention to ensuring that the motivational factors help employees to find their worth with respect to the value given to them by the organization. This, in turn, will increase employees' motivational levels and ultimately raise their happiness, which will cause job satisfaction. Furthermore, work motivation is likely to result in greater employees' loyalty, commitment, efficiency, and productivity. Given these considerations, the following hypothesis is proposed:

$\mathrm{H}_{3}$ : Work motivation is positively associated with job satisfaction.

\subsubsection{Mediating effect of work motivation}

The work environment is one aspect of the organization perceived by its employees. It can influence employees' behaviour and level of job satisfaction. Meanwhile, motivation 
also plays a considerable role in influencing employees to deliver high performance and achieve satisfaction in their work (Raziq and Maulabakhsh 2015). Motivation concerns employees' willingness to devote extensive efforts to accomplishing the organization's goals (Tremblay et al. 2009). Utami et al. (2016) assert that work environmental factors can affect work motivation. If an organization's work environment combines ideal quantitative demands, a high level of role and duty clarity, and social support and assistance through supervisors or managers, then employees will be encouraged and motivated to produce their best for the company, which in turn fosters job satisfaction. Accordingly, the following hypothesis is proposed:

$\mathrm{H}_{4}$ : Work motivation significantly mediates the relationship between work environmental factors and job satisfaction.

\section{Method}

\subsection{Sample and procedures}

The data were collected through a questionnaire survey administered to middle and top managers in Jordanian commercial banks. The banking sector was selected because banks tend to compete with each another, and it is imperative to adopt leading edge technology, and employ high skilled labour force while investing heavily in improving the work environment that has been characterized by a rapidly changing environment. For instance, the banking sector is considered the first mover in the market, and so needs to develop and maintain a healthy motivating environment that supports and satisfies employees to maximise their performance (Al-Fayoumi and Abuzayed 2009). The research population comprised over 1,000 employees across 13 commercial banks listed on the Amman Stock Exchange (ASE) in Jordan. For this population, a sample of 278 is considered representative (Sekaran and Bougie 2013). The units of analysis for this study are all middle and top managers.

The questionnaire survey was face-validated by three professors of Organisational Behaviour and pilot tested on 25 managers from Jordanian commercial banks, of whom 24 returned valid responses. Based on the professors and managers' feedback, the sequencing and language of the questions were modified. In the finalised questionnaire, all respondents were asked to evaluate their agreement or disagreement with each statement on a five-point Likert scale, ranging from $1=$ strongly disagree to $5=$ strongly agree. Based on proportional sampling, 500 questionnaires were distributed across the 13 banks. In each bank, the questionnaires were distributed to employees using simple random sampling. The number of returned questionnaires, 295, with a response rate of $59 \%$ is suitable for analysis.

\subsection{Measurements}

Work environmental factors were measured with an 18item scale that covers four dimensions: quantitative demands, job insecurity, social support from supervisors, and role clarity (Bjorner and Pejtersen 2010, Kristensen et al. 2005, Rosário et al. 2017). To measure work motivation, a nine-item scale was used, comprising three items for each of three dimensions: intrinsic motivation, integrated regulation, and external regulation (Gagné et al. 2015, Tremblay et al. 2009). Finally, job satisfaction was measured with a 13-item scale covering three dimensions: job characteristics, rewards, and job stress (Yuen et al. 2018). The final construct measures are presented in Table 1 below.

Table 1. Measurement Items

\begin{tabular}{|c|c|}
\hline Item number & Item descriptions \\
\hline \multicolumn{2}{|c|}{ Work environmental factors } \\
\hline QD1 & \multirow{3}{*}{ Quantitative demands } \\
\hline QD2 & \\
\hline QD3 & \\
\hline JI1 & \multirow{4}{*}{ Job insecurity } \\
\hline $\mathrm{JI} 2$ & \\
\hline JI3 & \\
\hline JI4 & \\
\hline SS1 & \multirow{3}{*}{$\begin{array}{l}\text { Social support from } \\
\text { supervisors }\end{array}$} \\
\hline SS2 & \\
\hline SS3 & \\
\hline $\mathrm{RC} 1$ & \multirow{4}{*}{ Role clarity } \\
\hline $\mathrm{RC} 2$ & \\
\hline RC3 & \\
\hline $\mathrm{RC} 4$ & \\
\hline \multicolumn{2}{|l|}{ Work motivation } \\
\hline IM1 & \multirow{3}{*}{ Intrinsic motivation } \\
\hline IM2 & \\
\hline IM3 & \\
\hline IR1 & \multirow{3}{*}{ Integrated regulation } \\
\hline IR2 & \\
\hline IR3 & \\
\hline ER1 & \multirow{3}{*}{ External regulation } \\
\hline ER2 & \\
\hline ER3 & \\
\hline \multicolumn{2}{|l|}{ Job satisfaction } \\
\hline JC1 & \multirow{5}{*}{ Job characteristics } \\
\hline JC2 & \\
\hline JC3 & \\
\hline $\mathrm{JC} 4$ & \\
\hline JC5 & \\
\hline
\end{tabular}


End of Table 1

\begin{tabular}{|l|l|}
\hline \multicolumn{1}{|c|}{ Item number } & \multicolumn{1}{|c|}{ Item descriptions } \\
\hline RW1 & \multirow{2}{*}{ Rewards } \\
\cline { 1 - 1 } RW2 & \\
\hline RW3 & \\
\cline { 1 - 1 } RW4 & \multirow{2}{*}{ Job stress } \\
\hline JS1 & \\
\hline JS2 & \\
\hline JS3 & \\
\hline JS4
\end{tabular}

\subsection{Validity and reliability}

To confirm construct validity, exploratory factor analysis (EFA) and confirmatory factor analysis (CFA) were used. EFA was executed using principal component analysis and the Promax rotation method. To examine whether the data collected were appropriate for factor analysis, both the Kaiser-Meyer-Olkin (KMO) measure of sampling adequacy and Bartlett's test of sphericity were used (Hair et al. 2010). The KMO and Bartlett's results confirm that factor analysis is suitable: the KMO statistics of all the constructs exceeded 0.50, and Bartlett's test revealed significant statistics for all the scales $(\mathrm{p}<0.05)$. The pattern matrix showed ten distinct factors with loadings larger than 0.40 and eigenvalues larger than one.

Based on these EFA results, a CFA was performed. The findings revealed a good fit: Chi-square to degrees of freedom $(\mathrm{CMIN} / \mathrm{DF})=2.12$; goodness-of-fit index $(\mathrm{GFI})=$ 0.921 ; comparative fit index $(\mathrm{CFI})=0.919$; root mean square error of approximation (RMSEA) $=0.062$ (see Table 2). Moreover, following the guidelines of Hair et al. (2010), composite reliability (CR) was examined to measure internal consistency reliability. For each of the constructs, the $\mathrm{CR}$ value exceeded 0.60 , confirming that the measurement model has internal consistency reliability. Further, convergent validity was assessed using the average variance extracted (AVE). Each construct was found to have an AVE value exceeding 0.50 , which represents excellent convergent validity (Byrne 2010, Hair et al. 2010).

To confirm the reliability of the measurement scales, Cronbach's $a$ tests were conducted for each scale. The Cronbach's a coefficients for every scale exceeded 0.70 , which demonstrates adequate internal consistency (Hair et al. 2010). The final construct items are shown in Table 2.

Table 2. Construct validity and reliability

\begin{tabular}{|c|c|c|c|c|c|c|c|c|}
\hline Constructs & Item number & Means & $\begin{array}{l}\text { Standard } \\
\text { deviation }\end{array}$ & $\begin{array}{c}\text { Cronbach's } \\
\text { alpha }\end{array}$ & $\begin{array}{l}\text { Loadings } \\
\text { (EFA) }\end{array}$ & $\begin{array}{l}\text { Loadings } \\
\text { (CFA) }\end{array}$ & $\mathrm{CR}$ & AVE \\
\hline \multirow{3}{*}{$\begin{array}{l}\text { Quantitative } \\
\text { demands }\end{array}$} & QD1 & \multirow{3}{*}{4.029} & \multirow{3}{*}{0.521} & \multirow{3}{*}{0.764} & 0.65 & 0.824 & \multirow{3}{*}{0.774} & \multirow{3}{*}{0.536} \\
\hline & QD2 & & & & 0.784 & 0.732 & & \\
\hline & QD3 & & & & 0.521 & 0.628 & & \\
\hline \multirow{4}{*}{ Job insecurity } & JI1 & \multirow{4}{*}{3.905} & \multirow{4}{*}{0.489} & \multirow{4}{*}{0.855} & 0.633 & 0.679 & \multirow{4}{*}{0.806} & \multirow{4}{*}{0.510} \\
\hline & $\mathrm{JI} 2$ & & & & 0.725 & 0.713 & & \\
\hline & JI3 & & & & 0.605 & 0.692 & & \\
\hline & JI4 & & & & 0.725 & 0.769 & & \\
\hline \multirow{3}{*}{$\begin{array}{l}\text { Social } \\
\text { support from } \\
\text { supervisors }\end{array}$} & SS1 & \multirow{3}{*}{3.863} & \multirow{3}{*}{0.602} & \multirow{3}{*}{0.787} & 0.707 & 0.767 & \multirow{3}{*}{0.754} & \multirow{3}{*}{0.506} \\
\hline & SS2 & & & & 0.616 & 0.667 & & \\
\hline & SS3 & & & & 0.666 & 0.696 & & \\
\hline \multirow{4}{*}{ Role clarity } & RC1 & \multirow{4}{*}{4.033} & \multirow{4}{*}{0.544} & \multirow{4}{*}{0.761} & 0.717 & 0.816 & \multirow{4}{*}{0.811} & \multirow{4}{*}{0.52} \\
\hline & RC2 & & & & 0.707 & 0.684 & & \\
\hline & RC3 & & & & 0.685 & 0.615 & & \\
\hline & RC4 & & & & 0.721 & 0.755 & & \\
\hline \multirow{3}{*}{$\begin{array}{l}\text { Intrinsic } \\
\text { motivation }\end{array}$} & IM1 & \multirow{3}{*}{4.064} & \multirow{3}{*}{0.558} & \multirow{3}{*}{0.73} & 0.671 & 0.734 & \multirow{3}{*}{0.771} & \multirow{3}{*}{0.529} \\
\hline & IM2 & & & & 0.505 & 0.699 & & \\
\hline & IM3 & & & & 0.57 & 0.749 & & \\
\hline & IR1 & & & & 0.786 & 0.787 & & \\
\hline Integrated & IR2 & 4.09 & 0.538 & 0.812 & 0.702 & 0.813 & 0.799 & 0.572 \\
\hline & IR3 & & & & 0.674 & 0.66 & & \\
\hline & ER1 & & & & 0.692 & 0.787 & & \\
\hline $\begin{array}{l}\text { External } \\
\text { reoulation }\end{array}$ & ER2 & 4.137 & 0.592 & 0.75 & 0.739 & 0.738 & 0.751 & 0.504 \\
\hline & ER3 & & & & 0.558 & 0.591 & & \\
\hline & $\mathrm{JC1}$ & & & & 0.683 & 0.688 & & \\
\hline & JC2 & & & & 0.899 & 0.804 & & \\
\hline Job & JC3 & 4.039 & 0.548 & 0.838 & 0.829 & 0.797 & 0.845 & 0.525 \\
\hline cnaracteristics & JC4 & & & & 0.565 & 0.584 & & \\
\hline & JC5 & & & & 0.606 & 0.727 & & \\
\hline
\end{tabular}




\begin{tabular}{|c|c|c|c|c|c|c|c|c|}
\hline Constructs & Item number & Means & $\begin{array}{r}\text { Standard } \\
\text { deviation }\end{array}$ & $\begin{array}{c}\text { Cronbach's } \\
\text { alpha }\end{array}$ & $\begin{array}{l}\text { Loadings } \\
\text { (EFA) }\end{array}$ & $\begin{array}{c}\text { Loadings } \\
\text { (CFA) }\end{array}$ & CR & AVE \\
\hline \multirow{4}{*}{ Rewards } & RW1 & \multirow{4}{*}{4.127} & \multirow{4}{*}{0.595} & \multirow{4}{*}{0.817} & 0.703 & 0.794 & \multirow{4}{*}{0.82} & \multirow{4}{*}{0.535} \\
\hline & RW2 & & & & 0.748 & 0.8 & & \\
\hline & RW3 & & & & 0.595 & 0.687 & & \\
\hline & RW4 & & & & 0.737 & 0.631 & & \\
\hline \multirow{4}{*}{ Job stress } & JS1 & \multirow{4}{*}{4.131} & \multirow{4}{*}{0.519} & \multirow{4}{*}{0.759} & 0.612 & 0.669 & \multirow{4}{*}{0.813} & \multirow{4}{*}{0.521} \\
\hline & JS2 & & & & 0.571 & 0.78 & & \\
\hline & JS3 & & & & 0.519 & 0.694 & & \\
\hline & JS4 & & & & 0.658 & 0.739 & & \\
\hline \multirow{4}{*}{$\begin{array}{l}\text { Work } \\
\text { environmental } \\
\text { factors }^{\text {a }}\end{array}$} & $\mathrm{QD}^{\mathrm{b}}$ & \multirow{4}{*}{3.959} & \multirow{4}{*}{0.435} & \multirow{4}{*}{0.863} & 0.667 & 0.643 & \multirow{4}{*}{0.819} & \multirow{4}{*}{0.534} \\
\hline & $\mathrm{JI}^{\mathrm{b}}$ & & & & 0.679 & 0.752 & & \\
\hline & $S S^{b}$ & & & & 0.673 & 0.692 & & \\
\hline & $\mathrm{RC}^{\mathrm{b}}$ & & & & 0.709 & 0.823 & & \\
\hline \multirow{3}{*}{$\begin{array}{l}\text { Work } \\
\text { motivation }^{\text {a }}\end{array}$} & $\mathrm{IM}^{\mathrm{b}}$ & \multirow{3}{*}{4.097} & \multirow{3}{*}{0.490} & \multirow{3}{*}{0.850} & 0.589 & 0.847 & \multirow{3}{*}{0.858} & \multirow{3}{*}{0.668} \\
\hline & $\mathrm{IR}^{\mathrm{b}}$ & & & & 0.730 & 0.804 & & \\
\hline & $\mathrm{ER}^{\mathrm{b}}$ & & & & 0.665 & 0.800 & & \\
\hline \multirow{3}{*}{$\begin{array}{l}\text { Job } \\
\text { satisfaction a }\end{array}$} & $\mathrm{JC}^{\mathrm{b}}$ & \multirow{3}{*}{4.094} & \multirow{3}{*}{0.509} & \multirow{3}{*}{0.922} & 0.718 & 0.823 & \multirow{3}{*}{0.872} & \multirow{3}{*}{0.694} \\
\hline & $\mathrm{RW}^{\mathrm{b}}$ & & & & 0.699 & 0.856 & & \\
\hline & $\mathrm{JS}^{\mathrm{b}}$ & & & & 0.601 & 0.820 & & \\
\hline
\end{tabular}

${ }^{\mathrm{a}}$ Second-order factors; ${ }^{\mathrm{b}}$ Second-order indicators.

Notes: $\mathrm{CR}=$ composite reliability; $\mathrm{AVE}=$ average variance extracted.

Discriminant validity, maximum shared variance (MSV), average shared variance (ASV), and inter-construct correlations were calculated to ensure that the square root of each AVE value exceeded the absolute correlation value between that construct and other constructs. Since both MSV and ASV are less than their corresponding AVEs, there is strong support for discriminant validity (Hair et al. 2010) (Table 3).

Table 3. Assessment of discriminant validity

\begin{tabular}{|l|c|c|c|c|c|}
\hline \multicolumn{1}{|c|}{ Constructs } & MSV & ASV & 1 & 2 & 3 \\
\hline $\begin{array}{l}\text { Work environ- } \\
\text { mental factors }\end{array}$ & 0.513 & 0.496 & $0.721^{\mathrm{a}}$ & & \\
\hline $\begin{array}{l}\text { Work } \\
\text { motivation }\end{array}$ & 0.513 & 0.504 & $0.716^{* *}$ & $0.817^{\mathrm{a}}$ & \\
\hline Job satisfaction & 0.596 & 0.487 & $0.692^{* *}$ & $0.704^{* *}$ & $0.833^{\mathrm{a}}$ \\
\hline
\end{tabular}

a The square root of AVE is shown in bold along the diagonal.

Notes: MSV = maximum shared variance; ASV = average shared variance.

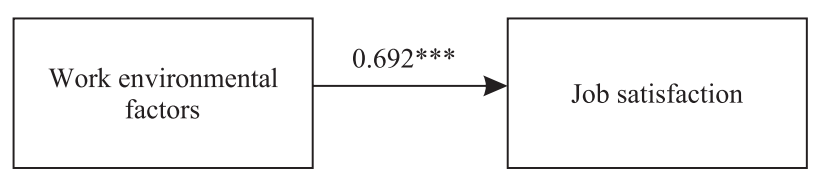

Note: ${ }^{* *}: \mathrm{p}<0.001$.

Figure 2. Effect of work environmental factors on job satisfaction

\section{Results}

Structural equation modelling (SEM) using Amos 24 was used to test the research hypotheses. The first step was to test the direct effect of work environmental factors on job satisfaction $\left(\mathrm{H}_{1}\right)$ without including the mediating variable (work motivation). The estimate of the standardized regression weight (beta value) from work environmental factors to job satisfaction was positive and significant $(\beta=$ $0.692, \mathrm{P}<0.01$ ); consequently, $\mathrm{H}_{1}$ was supported. Figure 2 illustrates the test result.

To test the other hypotheses and the mediating effect, the mediation analysis approaches of Baron and Kenny (1986) and Hayes (2013) were adopted. Including mediation in the model reduced the effect of work environmental factors on job satisfaction $(\beta=0.257, \mathrm{p}<0.001)$. According to Baron and Kenny (1986), work motivation partially mediates the relationship between work environmental factors and job satisfaction. Mediation was also tested using a bootstrapping re-sampling method (Shrout and Bolger 2002). A total of 5,000 bias-corrected bootstrapping resamples with a $95 \%$ confidence interval were generated in the path model. The presence of the indirect effect in the $95 \%$ confidence interval confirms that the mediating effect is valid (Hayes 2013). Figure 3 illustrates the test results.

The results of the mediation model indicate that the effect of work environmental factors on work motivation is 


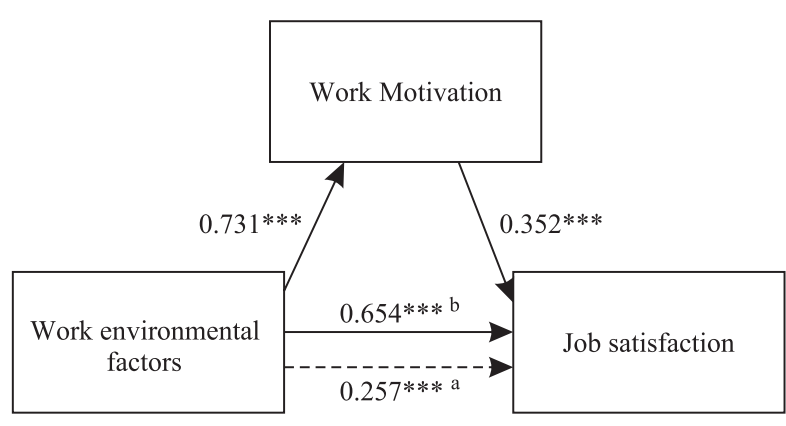

Note: ${ }^{* *}: \mathrm{p}<0.001{ }^{\mathrm{a}}:$ indirect effect; ${ }^{\mathrm{b}}$ : direct effect.

Figure 3. The mediation effect of work motivation in the relationship between work environmental factors and job satisfaction

positive and significant $(\beta=0.731, \mathrm{P}<0.001)$; therefore, $\mathrm{H}_{2}$ was supported. Also, the effect of work motivation on job satisfaction was significant $(\beta=0.352, P>0.05)$; therefore, $\mathrm{H}_{3}$ is supported. The goodness-of-fit indices for this model are acceptable: the CMIN/DF value of 2.806 implies a statistically significant effect at the 0.01 level. With CFI $=0.949$, $\mathrm{GFI}=0.956$, and RMSEA $=0.078$, the model fits the data reasonably well. Thus, $\mathrm{H}_{2}, \mathrm{H}_{3}$, and $\mathrm{H}_{4}$ are supported.

Additional tests were conducted to explore whether work environmental factors and job satisfaction differ according to the number of employees, age, job titles, and educational levels. However, no significant differences were found, so these results are not reported.

\section{Discussion}

This study proposed four hypotheses to examine the effect of work environmental factors on job satisfaction, with work motivation as a mediating variable. The study's results indicate that work environmental factors positively affect the dimensions of job satisfaction, consistent with prior research (e.g. Abualrub et al. 2016, Agbozo et al. 2017, Ayamolowo 2013, Bojadjiev et al. 2015). This finding highlights the essential role of work environmental factors (specifically quantitative demands, job insecurity, social support from supervisors, and role clarity) in promoting job satisfaction.

More specifically, quantitative demands that ideally balance available time and the amount of work to be done reinforce job satisfaction (Kristensen et al. 2004). Job insecurity, as the perceived threat of losing one's job based on organizational cues or fears about the future of the role, is associated with increased job stress, fear, and anxiety (Probst et al. 2017), and so lower job satisfaction. Conversely, more extended social support from supervisors or managers and higher clarity in the role and its duties influence positively job satisfaction in terms of rewards, job characteristics, and job stress reduction (Suleiman et al. 2017).
The findings also reveal that work environmental factors positively affect work motivation, consistent with prior studies (e.g. Dawal and Taha 2006, Jayaweera 2015, Muchtar 2017). A work environment that sets clear expectations regarding individuals' work roles, and offers positive emotional and material aids to the employees (i.e. social support from supervisors) will positively influence the individuals' intrinsic and extrinsic motivation to work to achieve organizational goals. By contrast, in a work environment characterised by job insecurity, employees might act as requested, or at least go through the motions of performing assigned tasks, only to obtain a reward (external regulation), but are unlikely to have self-determined motivation (Tremblay et al. 2009). The results also provide strong evidence that work motivation, in terms of intrinsic motivation, integrated regulation, and external regulation, positively affects job satisfaction, again consistently with prior studies (e.g. Raziq and Maulabakhsh 2015). This demonstrates that motivation plays an integral part in job satisfaction (Dawal and Taha 2006). Accordingly, managers should pay close attention to ensuring that their employees work in an appropriate and motivating environment, since motivation increases employees' loyalty, commitment, and job satisfaction.

This study also confirmed the mediating role of work motivation in the association between work environmental factors and job satisfaction, consistent with the results of Elnaga (2012), Jayaweera 2015, and Muchtar (2017). As discussed earlier, the work environment combines the work itself and the contextual factors that foster or inhibit job satisfaction through the level of motivation. To achieve competitive advantages in any work environment, work environmental factors (such as job security, social support from supervisors, role clarity, and quantitative demands that optimally balance between available time and the amount of work), and a highly motivated workforce are needed to boost employees' job satisfaction (Tremblay et al. 2009). As such, work motivation is closely related to work environmental factors and positively affects job satisfaction.

\section{Conclusions}

This paper aimed to explore empirically how non-physical work environmental factors affect job satisfaction through the mediating role of work motivation. For this purpose, it focused on 13 commercial banks operating in Jordan. This is among the first studies to investigate how psychological factors related to the work environment affect work motivation and job satisfaction.

A comprehensive review of the literature identified the underlying dimensions associated with work environmental factors, job satisfaction, and work motivation, thus informing the development of a conceptual model focused on work psychological attributes. By identifying the conceptual relations among work psychological attributes, this 
study contributes to developing theoretical and empirical approaches in organizational theory and behaviour.

The results of SEM analysis revealed that work motivation positively and significantly mediates the association between work environmental factors and job satisfaction. This finding is attributable to the work itself and contextual factors contributing to employees' positive feelings towards their jobs through work motivation. The findings also confirm a positive and significant effect of work environmental factors on work motivation, and that work motivation subsequently enhances job satisfaction.

\section{Managerial implications}

The theoretical and managerial contributions of this study are twofold. First, by formulating a comprehensive model of the work environmental factors, this paper contributes to theory and practice. The study's findings potentially provide inputs to the policy-makers in Jordanian commercial banks, helping them realize its work environment and development. The study extends research in the area of work motivation and job satisfaction and offers a set of measures to assess those variables, helping researchers and practitioners to develop empirical and action studies that explore more deeply the proposed effects.

Second, the study's supported hypotheses can practically help commercial bank managers to improve work motivation and job satisfaction. The study underscores that work environmental factors (such as job insecurity) and lower work motivation (such as external regulation) lead towards lower job satisfaction. Therefore, if the existing scenario (job insecurity and low work motivation) persists and remains unaddressed in Jordan's commercial banks, it could lead to a discouraging work environment and serious issues of employees' work-related stress. Also, it could determine a breakdown in employees' job satisfaction.

\section{Limitations and future research}

This research is not free from limitations. First, the questionnaire survey was directed only to commercial banks in Jordan. Measuring middle and top managers' perceptions in a single industry allows for maximal control over the contextual and psychological work environment. However, it limits the external generalizability of the study's findings. Future research should expand this study's approach across various industries to enhance generalizability.

Secondly, the study employed a cross-sectional research design to answer the two research questions. While this comprehensively served the study's purpose, it has the weakness of single-impression data. Future research could address this by using a longitudinal research design.

Another possible area to explore is the moderating effects within the proposed framework. For instance, we examined the association between work environmental factors and job satisfaction, but other aspects might influence their relationships as well. Future studies should further investigate the work environmental factors that contribute to create a sense of confidence and loyalty toward the organization and improve the quality of outcomes.

\section{References}

Abualrub R, El-Jardali F, Jamal D, Al-Rub NA (2016) Exploring the relationship between work environment, job satisfaction, and intent to stay of Jordanian nurses in underserved areas. Applied Nursing Research 31: 19-23. https://doi.org/10.1016/j.apnr.2015.11.014

Agbozo GK, Owusu IS, Hoedoafia MA, Atakorah YB (2017) The effect of work environment on job satisfaction: evidence from the banking sector in Ghana. Journal of Human Resource Management 5 (1): 12-18.

https://doi.org/10.11648/j.jhrm.20170501.12

Ahluwalia AK, Preet K (2017) The influence of organizational commitment on work motivation: a comparative study of state and private university teachers. IUP Journal of Organizational Behavior 16 (2): 55 .

Aksoy C, Sengül HI, Yilmaz Y (2018) Examination of the relationship between job satisfaction levels and organizational commitments of tourism sector employees: a research in the South Eastern Anatolia region of Turkey. Elektronik Sosyal Bilimler Dergisi 17 (65): 356-365.

https://doi.org/10.17755/esosder.343032

Al-Fayoumi NA, Abuzayed BM (2009) Assessment of the Jordanian banking sector within the context of GATS agreement. Banks and Bank Systems 4 (2): 69-79.

Alhassan RK, Spieker N, van Ostenberg P, Ogink A, NketiahAmponsah E, de Wit TFR (2013) Association between health worker motivation and healthcare quality efforts in Ghana. Human Resources for Health 11 (1): 37. https://doi.org/10.1186/1478-4491-11-37

Appu AV, Kumar Sia S (2015) Organizational social support: a predictor of employees workplace creativity. Annamalai International Journal of Business Studies \& Research (Spec. 1): 1-5 http://connection.ebscohost.com/c/articles/109025169/ organizational-social-support-predictor-employees-workplace-creativity

Arsalani N, Fallahi-Khoshknab M, Ghaffari M, Josephson M, Lagerstrom M (2011) Adaptation of questionnaire measuring working conditions and health problems among Iranian nursing personnel. Asian Nursing Research 5 (3): 177-182. https://doi.org/10.1016/j.anr.2011.09.004

Atefi N, Abdullah KL, Wong LP, Mazlom R (2014) Factors influencing registered nurses' perception of their overall job satisfaction: a qualitative study. International Nursing Review 61 (3): 352-360. https://doi.org/10.1111/inr.12112

Ayamolowo SJ (2013) Job satisfaction and work environment of primary health care nurses in Ekiti State, Nigeria: An exploratory study. International Journal of Caring Sciences 6 (3): 531.

Baron R, Kenny D (1986) The moderator-mediator variable distinction in social psychological research: conceptual, 
strategic, and statistical considerations. Journal of Personality and Social Psychology 51 (6): 1173-1182.

https://doi.org/10.1037/0022-3514.51.6.1173

Bhattacharya SM, Sengupta N (2007) Emotional intelligence: myth or reality. New Delhi: Excel Books.

Bjorner JB, Pejtersen JH (2010) Evaluating construct validity of the second version of the Copenhagen Psychosocial Questionnaire through analysis of differential item functioning and differential item effect. Scandinavian Journal of Public Health 38 (3_suppl): 90-105.

https://doi.org/10.1177/1403494809352533

Bojadjiev M, Petkovska MS, Misoska AT, Stojanovska J (2015) Perceived work environment and job satisfaction among public administration employees. The European Journal of Applied Economics 12 (1): 10-18.

https://doi.org/10.5937/ejae12-8154

Bratton J, Gold J (2017) Human resource management: theory and practice (6th ed). Palgrave Macmillan, London.

Byrne BM (2010) Structural equation modelling with AMOS: Basic concepts, applications, and programming. New York: Routledge.

Canan HOŞ, Oksay A (2015) Hemşirelerde Örgütsel Bağlılık İle İş Tatmini İlişkisi. Süleyman Demirel Üniversitesi İktisadi ve İdari Bilimler Fakültesi Dergisi 20 (4).

Clark CAC, Pritchard VE, Woodward LJ (2010) Preschool executive functioning abilities predict early mathematics achievement. Developmental Psychology 46 (5): 1176-1191. https://doi.org/10.1037/a0019672

Curnin S, Owen C, Paton D, Trist C, Parsons D (2015) Role clarity, swift trust and multi-agency coordination. Journal of Contingencies and Crisis Management 23 (1): 29-35. https:// doi.org/10.1111/1468-5973.12072

Dawal SZM, Taha Z (2006) The effect of job and environmental factors on job satisfaction in automotive industries. International Journal of Occupational Safety and Ergonomics 12 (3): 267-280. https://doi.org/10.1080/10803548.2006.11076687

De Cuyper N, De Witte H (2007) Job insecurity in temporary versus permanent workers: Associations with attitudes, wellbeing, and behaviour. Work \& Stress 21 (1): 65-84. https://doi.org/10.1080/02678370701229050

Devi KR, Rani SS (2016) The impact of organizational role stress and work family conflict: diagnosis sources of difficulty at work place and job satisfaction among women in IT Sector, Chennai, Tamil Nadu. Procedia-Social and Behavioral Sciences 219: 214-220. https://doi.org/10.1016/j.sbspro.2016.05.008

Elnaga AA (2012) Exploring the link between job motivation, work environment and job satisfaction. Journal of American Science 8 (11): 180-185.

Fairbrother K, Warn J (2003) Workplace dimensions, stress and job satisfaction. Journal of Managerial Psychology 18 (1): 8-21. https://doi.org/10.1108/02683940310459565

Gagné M, Forest J, Vansteenkiste M, Crevier-Braud L, Van den Broeck A, Aspeli AK, Bellerose J, Benabou C, Chemolli E, Güntert ST, Halvari H (2015) The multidimensional work motivation scale: validation evidence in seven languages and nine countries. European Journal of Work and Organizational Psychology 24 (2): 178-196.

https://doi.org/10.1080/1359432X.2013.877892
Ganzach Y, Fried I (2012) The role of intelligence in the formation of well-being: From job rewards to job satisfaction. Intelligence 40 (4): 333-342. https://doi.org/10.1016/j.intell.2012.03.004

Gene Alarcon, Eschleman KJ, NA Bowling (2009) Relationships between personality variables and burnout: A meta-analysis. Work \& Stress 23 (3): 244-263. https://doi.org/10.1080/02678370903282600

Green F (2011) Unpacking the misery multiplier: How employability modifies the impacts of unemployment and job insecurity on life satisfaction and mental health. Journal of Health Economics 30 (2): 265-276.

https://doi.org/10.1016/j.jhealeco.2010.12.005

Griffin MA, Patterson MG, West MA (2001) Job satisfaction and teamwork: The role of supervisor support. Journal of Organizational Behavior 22 (5): 537-550. https://doi.org/10.1002/job.101

Hackman JR, Oldham GR (1976) Motivation through the design of work: Test of a theory. Organizational Behavior and Human Performance 16 (2): 250-279. https://doi.org/10.1016/0030-5073(76)90016-7

Hair J, Black W, Babin B, Anderson R (2010) Multivariate data analysis. Upper Saddle River, NJ: Prentice Hall, Inc.

Halkos G, Bousinakis D (2017) The effect of stress and dissatisfaction on employees during crisis. Economic Analysis and Policy 55: 25-34. https://doi.org/10.1016/j.eap.2017.04.002

Hayes AF (2013) Introduction to mediation, moderation, and conditional process analysis. New York, NY: The Guilford Press.

Henderson LS, Stackman RW, Lindekilde R (2016) The centrality of communication norm alignment, role clarity, and trust in global project teams. International Journal of Project Management 34 (8): 1717-1730. https://doi.org/10.1016/j.ijproman.2016.09.012

Henderson RI (2003) Compensation management in a knowledge-based world. Upper Saddle River, NJ: Prentice Hall.

House JS (1981) Work stress and social support. Reading, MA: Addison-Wesley.

Jackson SE, Schuler RS (1985) A meta-analysis and conceptual critique of research on role ambiguity and role conflict in work settings. Organizational Behavior and Human Decision Processes 36 (1): 16-78. https://doi.org/10.1016/0749-5978(85)90020-2

Jayaweera T (2015) Impact of work environmental factors on job performance, mediating role of work motivation: A study of hotel sector in England. International Journal of Business and Management 10 (3): 271. https://doi.org/10.5539/ijbm.v10n3p271

Kristensen TS, Bjorner JB, Christensen KB, Borg V (2004) The distinction between work pace and working hours in the measurement of quantitative demands at work. Work \& Stress 18 (4): 305-322. https://doi.org/10.1080/02678370412331314005

Kristensen TS, Hannerz H, Høgh A, Borg V (2005) The Copenhagen Psychosocial Questionnaire-a tool for the assessment and improvement of the psychosocial work environment. Scandinavian Journal of Work, Environment \& Health: 438449. https://doi.org/10.5271/sjweh.948

Lane KA, Esser J, Holte B, McCusker MA (2010) A study of nurse faculty job satisfaction in community colleges in Florida. 
Teaching and Learning in Nursing 5 (1): 16-26.

https://doi.org/10.1016/j.teln.2009.05.001

Lee WJ, Lee JK (2017) Role clarity and organizational commitment in food manufacturing and distribution firms: the mediating role of creativity. Distribution Science Research 15: 115-121. https://doi.org/10.15722/jds.15.1.201701.115

Li KX, Yin J, Luo M, Wang J (2014) Leading factors in job satisfaction of Chinese seafarers. International Journal of Shipping and Transport Logistics 6 (6): 680-693.

https://doi.org/10.1504/IJSTL.2014.064923

Lucas JW, Whitestone Y, Segal DR, Segal MW, White MA, Ve Mottern JA (2009) Social support and turnover: review and recommendations. Current Topics in Management: 49-72. https://doi.org/10.4324/9780203793985-3

Muchtar M (2017) The influence of motivation and work environment on the performance of employees. Sinergi: Jurnal Ilmiah Ilmu Manajemen 6 (2): 27-40. https://doi.org/10.25139/sng.v6i2.80

Na-Nan K, Pukkeeree P (2013) Influence of job characteristics and job satisfaction effect work adjustment for entering labor market of new graduates in Thailand. International Journal of Business and Social Science 4 (2).

Opperman CS (2002) Tropical business issues. Partner Price Water House Coopers, International Business Review.

Petreanu V, Iordache R, Seracin M (2013) Assessment of work stress influence on work productivity in Romanian companies. Procedia-Social and Behavioral Sciences 92: 420-425. https://doi.org/10.1016/j.sbspro.2013.08.695

Probst TM, Gailey NJ, Jiang L, Bohle SL (2017) Psychological capital: Buffering the longitudinal curvilinear effects of job insecurity on performance. Safety Science 100: 74-82. https:// doi.org/10.1016/j.ssci.2017.02.002

Rabideau ST (2005) Effects of achievement motivation on behaviour http://www.personalityresearch.org/papers/rabideau. html

Raziq A, Maulabakhsh R (2015) Impact of work environment on job satisfaction. Procedia Economics and Finance 23: 717725. https://doi.org/10.1016/S2212-5671(15)00524-9

Rosário S, Azevedo LF, Fonseca JA, Nienhaus A, Nübling M, da Costa JT (2017) The Portuguese long version of the Copenhagen Psychosocial Questionnaire II (COPSOQ II) - a validation study. Journal of Occupational Medicine and Toxicology 12 (1): 24. https://doi.org/10.1186/s12995-017-0170-9

Ryan RM, Deci EL (2000) Self-determination theory and the facilitation of intrinsic motivation, social development, and well-being. American Psychologist 55: 68-78. https://doi.org/10.1037//0003-066X.55.1.68

Sarrasin B, Arseneault P, Boivin M (2017) Linking satisfaction to motivation determinants: Canadians' travel to the Caribbean. Management \& Avenir 6 (96): 123-142. https://doi.org/10.3917/mav.096.0123

Seckin-Celik T, Çoban A (2016) The effect of work stress and coping on organizational justice: an empirical investigation of Turkish telecommunications and banking industries. Management 11 (4): 271-28.
Sekaran U, Bougie R (2013) Research methods for business: a skill-building approach (6th ed). Wiley, New York.

Shrout P, Bloger N (2002) Mediation in experimental and nonexperimental studies: New procedures and recommendations. Psychological Methods 7 (4): 422-445. https://doi.org/10.1037/1082-989X.7.4.422

Sias PM (2009) Organizing relationships: traditional and emerging perspectives on workplace relationships. Thousand Oaks, CA: SAGE Publications, Inc.

Singh S, Sharma GD, Sharma R (2011) Effect of employee involvement in business organisation. Research Gate. https://doi.org/10.2139/ssrn.1852018

Snepenger D, King J, Marshall E, Uysal M (2006) Modeling IsoAhola's motivation theory in the tourism context. Journal of Travel Research 2006: 45, 140. https://doi.org/10.1177/0047287506291592

Spector PE (1997) Advanced topics in organization behaviour: job satisfaction: application, assessment, causes, and consequences. Thousand Oaks, CA: SAGE Publications, Inc. https://doi.org/10.4135/9781452231549

Suleiman W, Dassanayake MS, Othman AEA (2017) Mediation of transfer motivation on the relationship between supervisor support, peer support and transfer of training. International Journal of Business \& Society 18 (3): 605-617.

Tremblay MA, Blanchard CM, Taylor S, Pelletier LG, Villeneuve M (2009) Work extrinsic and intrinsic motivation scale: its value for organizational psychology research. Canadian Journal of Behavioural Science/Revue canadienne des sciences du comportement 41 (4): 213. https://doi.org/10.1037/a0015167

Utami PS, Hubeis M, Affandi M (2016) The impact of working climate and motivation towards job satisfaction that implies the employee performance in PT Indonesia power generation business unit of Suralaya Banten. International Journal of Scientific and Research Publications 6 (7): 26-31.

Wang H, Tang C, Zhao S, Meng Q, Liu X (2017) Job satisfaction among health-care staff in township health centers in rural China: results from a latent class analysis. International Journal of Environmental Research and Public Health 14 (10): 1101. https://doi.org/10.3390/ijerph14101101

Wanous JP, Reichers A, Hudy M (1997) Overall job satisfaction: How good are single item measures? Journal of Applied Psychology 82 (2): 247-252. https://doi.org/10.1037//0021-9010.82.2.247

Wen Lim H, Li N, Fang D, Wu C (2018) Impact of safety climate on types of safety motivation and performance: multigroup invariance analysis. Journal of Management in Engineering 34 (3): 04018002. https://doi.org/10.1061/(ASCE)ME.1943-5479.0000595

Wilson KG (2015) Impact of work environment on academic staff job performance: case of a Uganda university. International Journal of Advances in Management and Economics 4 (4): 95-103.

Yuen KF, Loh HS, Zhou Q, Wong YD (2018) Determinants of job satisfaction and performance of seafarers. Transportation Research Part A: Policy and Practice 110: 1-12. https://doi.org/10.1016/j.tra.2018.02.006 